\title{
(2) Delayed unilateral pneumocephalus after bilateral endoscopic dacryocystorhinostomy in an elderly patient
}

\author{
Jaekyoung Lee $(\mathbb{0}$, Dong Cheol Lee
}

Ophthalmology, Keimyung University College of Medicine, Daegu, Republic of Korea

Correspondence to Professor Dong Cheol Lee; tking33@naver.com

Accepted 25 April 2021
Check for updates

(c) BMJ Publishing Group Limited 2021. Re-use permitted under CC BY-NC. No commercial re-use. See rights and permissions. Published by BMJ.

To cite: Lee J, Lee DC. BMJ Case Rep 2021;14:e241540. doi:10.1136/bcr-2020-

241540

\section{SUMMARY}

Dacryocystorhinostomy (DCR) is the 'gold standard' treatment for nasolacrimal duct obstruction (NLDO). However, despite its recent technical advancements, complications are possible. Herein, to the best of our knowledge, we present the first reported case of delayed unilateral pneumocephalus after bilateral endoscopic DCR. An 85-year-old man with bilateral NLDO underwent endoscopic DCR with silicone intubation. After 1 month, he became lethargic and was admitted to emergency room. Brain CT demonstrated left pneumocephalus and a suspected microfistula in left orbital wall. Intravenous antibiotic therapy was started, and cerebrospinal fluid studies showed no evidence of meningitis. After 13 days of antibiotic treatment, his mental state recovered with no signs of pneumocephalus. Although DCR has high success rate and is relatively safe, surgeons should be aware of the risk, although low, of pneumocephalus, especially in elderly patients who are vulnerable to fractures and who exhibit headache or mental status changes after endoscopic DCR.

\section{BACKGROUND}

Dacryocystorhinostomy (DCR) is the 'gold standard' treatment for nasolacrimal duct obstruction (NLDO). ${ }^{1}$ Despite recent advancements in this surgical technique, complications-including bleeding, orbital infection, meningitis and pneumocephalus-still occur. Both pneumocephalus and meningitis are relatively rare complications of this procedure. There are only three published case reports of meningitis secondary to external DCR, ${ }^{2-4}$ and there are no published case reports of pneumocephalus secondary to endoscopic DCR. We present the first case report of delayed unilateral pneumocephalus after bilateral endoscopic DCR. This report adheres to the principles of the Declaration of Helsinki as amended in 2013.

\section{CASE PRESENTATION}

An 85-year-old Asian man visited our ophthalmology department with a multiyear history of epiphora and a binocular stinging sensation. He had a history of cerebrovascular accident and hypertension, old right lower lid canaliculitis, right-eye glaucoma surgery in 2010 and bilateral cataract surgery in 2015. During lacrimal canaliculi irrigation, both nasolacrimal ducts were obstructed. Consequently, the patient underwent bilateral endoscopic DCRs with silicone tube intubation. Standard surgical techniques are as follows and are also proceeded in our case accordingly; the middle turbinate is decongested for vasoconstriction. Using nasal endoscope, the lateral nasal mucosa adjacent to the lacrimal sac is incised. The nasal mucosa is then removed with endoscopic forceps, and the lacrimal bone is carefully removed with Kerrison rongeurs, with orbital rim kept intact. Bicanalicular silicone intubation is placed and nasal packing is done. During the operation, no marked anatomic variation was seen. $\mathrm{He}$ was discharged in good general condition 4 days after admission.

Four days later, he revisited our emergency room (ER) with reports of generalised weakness and poor oral intake without mental change or headache. His vital signs, blood tests and urinalysis showed no prominent abnormalities, and after hydration and supportive treatment, he was subsequently discharged with no ophthalmologic complication.

\section{INVESTIGATIONS}

One month later, the patient returned to our hospital and was admitted to the ER with lethargy and drowsy mentality for 2 days. At arrival, his silicone tube was well positioned with clear previous operation site. Physical examination including fiberoptic examination was unremarkable. He had no fever; however, his peripheral $\mathrm{C}$ reactive protein level was elevated to $7 \mathrm{mg} / \mathrm{dL}$, his erythrocyte sedimentation rate was increased to 95 , and his neutrophilic percentage was high at $87.30 \%$. Brain CT revealed a left pneumocephalus and potential microfistula in the left orbital wall, possibly secondary to his recent surgery (figure $1 \mathrm{~A}, \mathrm{~B}$ ). The patient had no cerebrospinal fluid (CSF) rhinorrhoea and no signs of bony dehiscence on nasal endoscopic examination. Chest CT revealed evidence of aspiration pneumonia.

\section{TREATMENT}

We administered empirical antibiotic therapy with $2 \mathrm{~g}$ vancomycin per day, $6 \mathrm{~g}$ ceftazidime per day and $1.5 \mathrm{~g}$ metronidazole per day for 13 days for postoperative pneumocephalus and aspiration pneumonia. Results of a lumbar puncture showed no evidence of meningitis, with clear CSF and no leukocytes.

\section{OUTCOME AND FOLLOW-UP}

After treatment with antibiotics for 13 days, the patient's brain CT showed no signs of persistent pneumocephalus (figure 2A,B), his mental status was fully recovered, and he was discharged.

\section{DISCUSSION}

DCR is a procedure that creates a new anastomosis between the lacrimal sac and nasal cavity. 

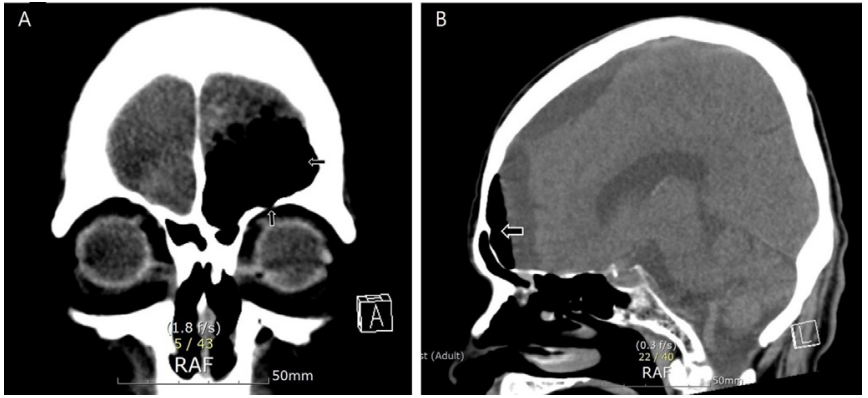

Figure 1 (A) Coronal view of brain CT demonstrating left pneumocephalus in the left anterior frontal convexity (horizontal arrow) and a suspected microfistula in the left orbital wall (vertical arrow). (B) Sagittal view of brain CT reveals pneumocephalus in the left anterior frontal convexity (horizontal arrow).

There are two main types of DCRs: external and endonasal. With recent advances in technology, it is possible to perform this procedure in patients who previously would have had contraindications, including advanced age or secondary acquired NLDO. Therefore, due to shorter operation time and recovery period, many elderly undergo DCR, and a few studies have focused on the success rate among older population. $^{5-7}$ Tessler et al found that the safety and longterm outcomes of the elderly are comparable with younger patients. ${ }^{5}$ On contrary, some studies revealed that the rate of revision surgery and risk of serious complication were higher in older patients. ${ }^{67}$ Although regarded as a relatively safe procedure, there is some degree of consensus to approach elderly population with caution during and after endoscopic surgery.

Overall success rate of endoscopic DCR is $86 \%$ at postoperatively 5 years and 10 years. Common complications include haemorrhage at $9 \%$ of patients, pain, synechiae in nasal cavity at $7 \%, 10 \%$, respectively. ${ }^{8}$ The synechiae between nasal septum and lateral wall and also between middle turbinate and lateral wall can be formed postoperatively. ${ }^{9}$ Intracranial complications including pneumocephalus are relatively rare complications of this procedure. To our knowledge, only a few cases of meningitis or pneumocephalus after external or endoscopic DCR have been reported. Beiran et al reported a case of meningitis in a 9-year-old woman, 1 day after external DCR. ${ }^{2}$ Usul et al reported a case of pneumocephalus 1 day after external DCR surgery in a 51 -year-old patient. ${ }^{3}$ CT imaging showed a fracture of the left fovea ethmoidalis, and after 3 weeks of antibiotics therapy, the patient was discharged. The most recent case was reported by Cheong and
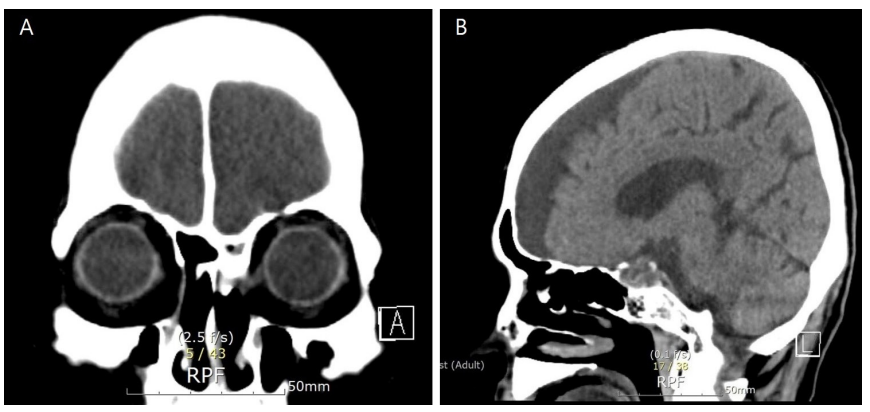

Figure 2 (A) Coronal view and (B) sagittal view of brain CT demonstrating resolution of pneumocephalus after admission and antibiotic treatment.
Davies. ${ }^{4}$ The 81 -year-old man developed meningoencephalitis after endoscopic DCR for unilateral NLDO. Two days postoperatively, he reported of a severe right-sided headache. CT scan showed a defect in right cranial fossa, and CSF study showed evidence of meningoencephalitis. He recovered fully after 11 days of intravenous antibiotics.

Our case differs from these previous reports because our patient was older and had a delayed unilateral pneumocephalus, which could have resulted from the physical impact of DCR surgery. Well-known risk factors of postoperative failure include older age and men. ${ }^{8}$ Moreover, elderly patients are particularly vulnerable to fractures, including skull fractures, owing to the osteoporotic changes that occur with ageing and exhibit delayed wound healing. ${ }^{10}$ As a result, any physical force-including surgery-can cause damage or create microfistulas in elderly patients. Few reports on DCR have addressed the risk of unintended opening of the meninges, which could result in meningitis, meningoencephalitis or CSF leakage. During osteotomy of the nasal bones in DCR, the cribriform plate, ethmoid air cells and superior border of the orbital wall can be injured by rotational and tractional forces. ${ }^{11-13} \mathrm{~A}$ fracture of the anterior cranial fossa floor can result from the rotational force of a Kerrison rongeur when the nasal window is enlarged or from fracture of the superior wall of an ethmoid air cell eroded into the orbital roof. ${ }^{13}$

Because our patient showed lethargy after DCR, intraoperative damage to the orbital roof may have contributed to his pneumocephalus. Though it is critical to keep the orbital rim intact during surgery, while using the rongeur for osteotomy and manipulating the middle turbinate, primary pressure would have been applied on the anterior frontal and orbital walls. Consequently, a microfistula in the weakened bony structure allowed air to be forced intracranially. Although no definite microfistula could be identified on brain CT imaging, it is reasonable to assume that the intracranial air may have been caused by an inadvertent opening of the meninges.

In conclusion, although DCR has a high success rate and is a relatively safe procedure, surgeons should be aware of the risk, although low, of pneumocephalus. In particular, elderly patients who are vulnerable to fractures due to osteoporotic changes of bone with headache or mental status changes after endoscopic DCR should be closely followed.

\section{Learning points}

While dacryocystorhinostomy is a standard procedure, complications can occur, including rare complications such as pneumocephalus and meningitis.

- Any physical force applied to an elderly patient, including surgery, can induce microfistulas and unintended meningeal openings.

- Surgeons should be aware of the risk, although low, of pneumocephalus after endoscopic dacryocystorhinostomy, particularly in elderly patients.

Contributors Conception and design, acquisition of data or analysis and interpretation of data: DCL and JL. Drafting the article or revising it critically for important intellectual content: JL. Final approval of the version published: DCL. Agreement to be accountable for the article and to ensure that all questions regarding the accuracy or integrity of the article are investigated and resolved: DCL and JL.

Funding The authors have not declared a specific grant for this research from any funding agency in the public, commercial or not-for-profit sectors.

Competing interests None declared. 
Patient consent for publication Obtained.

Provenance and peer review Not commissioned; externally peer reviewed.

Open access This is an open access article distributed in accordance with the Creative Commons Attribution Non Commercial (CC BY-NC 4.0) license, which permits others to distribute, remix, adapt, build upon this work non-commercially, and license their derivative works on different terms, provided the original work is properly cited and the use is non-commercial. See: http://creativecommons.org/ licenses/by-nc/4.0/.

\section{ORCID iD}

Jaekyoung Lee http://orcid.org/0000-0001-8532-217X

\section{REFERENCES}

1 Tarbet KJ, Custer PL, dacryocystorhinostomy E. Surgical success, patient satisfaction, and economic cost. Ophthalmology 1995;102:1065-70.

2 Beiran I, Pikkel J, Gilboa M, et al. Meningitis as a complication of dacryocystorhinostomy. Br J Ophthalmol 1994;78:417-8.

3 Usul H, Kuzeyli K, Cakir E, et al. Meningitis and pneumocephalus. A rare complication of external dacryocystorhinostomy. J Clin Neurosci 2004;11:901-2.

4 Cheong TZ, Davies RP. Meningoencephalitis following endoscopic dacryocystorhinostomy. Ophthalmic Plast Reconstr Surg 2019;35:e47-9.
5 Tessler I, Warman M, Amos I, et al. Endoscopic dacryocystorhinostomy among the old and oldest-old populations - A case control study. Auris Nasus Larynx 2021. doi:10.1016/j.anl.2021.02.010. [Epub ahead of print: 17 Mar 2021].

6 Tooley AA, Klingler KN, Bartley GB, et al. Dacryocystorhinostomy for acquired nasolacrimal duct stenosis in the elderly ( $\geq 80$ years of age). Ophthalmology 2017;124:263-7.

7 Ramadan $\mathrm{HH}$, VanMetre R. Endoscopic sinus surgery in geriatric population. Am J Rhinol 2004;18:125-7.

8 Cohen 0 , Amos I, Halperin D, et al. Five- and 10-year outcomes for primary endoscopic dacryocystorhinostomy: failure rate and risk factors. Laryngoscope 2021;131:10-16

9 Harugop AS, Mudhol RS, Rekha BK, et al. Endonasal dacryocystorhinostomy: a prospective study. Indian J Otolaryngol Head Neck Surg 2008;60:335-40.

10 Alejandro P, Constantinescu F. A review of osteoporosis in the older adult: an update. Rheum Dis Clin North Am 2018;44:437-51.

11 Yilmaz YF, Ozcan M, Titiz A, et al. Meningoencephalocele as a rare cause of cerebrospinal fluid fistula during dacryocystorhinostomy. Ophthalmic Plast Reconstr Surg 2008;24:240-1.

12 Botek AA, Goldberg SH. Margins of safety in dacryocystorhinostomy. Ophthalmic Surg 1993;24:320-2.

13 Neuhaus RW, Baylis HI. Cerebrospinal fluid leakage after dacryocystorhinostomy. Ophthalmology 1983;90:1091-5.

Copyright 2021 BMJ Publishing Group. All rights reserved. For permission to reuse any of this content visit https://www.bmj.com/company/products-services/rights-and-licensing/permissions/

BMJ Case Report Fellows may re-use this article for personal use and teaching without any further permission.

Become a Fellow of BMs Case Reports today and you can:

- Submit as many cases as you like

- Enjoy fast sympathetic peer review and rapid publication of accepted articles

- Access all the published articles

Re-use any of the published material for personal use and teaching without further permission

\section{Customer Service}

If you have any further queries about your subscription, please contact our customer services team on +44 (0) 2071111105 or via email at support@bmj.com.

Visit casereports.bmj.com for more articles like this and to become a Fellow 